DOI: $10.2478 / \mathrm{v} 10025-009-0009-6$

JOURNAL OF WATER

AND LAND DEVELOPMENT

J. Water Land Dev. No. 12, 2008: 113-125

\title{
Changes of springs' yield of Lublin Upland and Roztocze Region in 1998-2008
}

\author{
Zdzisław MICHALCZYK, Stanistaw CHMIEL, Stawomir GŁOWACKI, \\ Beata ZIELIŃSKA
}

University Maria Curie-Skłodowska, Department of Hydrography, ul. Akademicka 19, 20-033 Lublin, Poland; zdzislaw.michalczyk@umcs.lublin.pl

\begin{abstract}
Lublin Upland and Roztocze region are known for the occurrence of a large number of springs of high yield. These springs are fed mainly from Cretaceous or Tertiary water-bearing horizon. In order to determine variability of springs' yield, 61 selected springs were analysed in spring periods of the years 1998-2008. Collected hydrometric materials allowed for comparing average and extreme yield values of springs in various physiographic regions within the period of 11 years. Average value was $76.1 \mathrm{dm}^{3} \cdot \mathrm{s}^{-1}$, while the mean of the minimal yields was $44.7 \mathrm{dm}^{3} \cdot \mathrm{s}^{-1}$ and of the maximal $-132.7 \mathrm{dm}^{3} \cdot \mathrm{s}^{-1}$. Coefficient of irregularity of the springs' yield ranged from 1.5 to 5.0 , which may lead to the conclusion that the springs' yield is constant or varies slightly. In some cases the irregularity was higher but it was determined by hydrogeological, meteorological and local factors.
\end{abstract}

Key words: springs, yield, irregularity of yield, Lublin Upland and Roztocze Region

\section{INTRODUCTION}

In the years 1991-2000 scientists from the Department of Hydrography of UMCS carried field studies and spring mapping of the upland area between the Vistula and the Bug Rivers. In 1991 springs were registered in the western part of Lublin Upland (Źródła..., 1993), in 1994 - in the Roztocze Region (Źródła, 1996) and in 2000 - in the centre and eastern part of Lublin Upland (Źródła..., 2001). In total, information of about 1,600 existing springs - meant as natural, self-acting and concentrated outflow of groundwaters - on the area of about $12,200 \mathrm{~km}^{2}$ was gathered. Noteworthy, studies and spring measurements in the region have been conducted for over 100 years. First published information concerned outflows of ferriferous waters in the Czechówka River valley in Sławinek in the outskirts of Lublin (DOBORZYŃSKI, 1896) and the other springs near Lublin (KRISZTAFOWICZ, 1902). From the beginning of the 1950s, selected springs' yield in the Lublin region was periodically measured (CZARNECKA, 1965; REDEROWA, 1965; MALI- 
NOWSKI, 1974; MICHALCZYK, 1982; 1983a; 1983b; JANIEC, 1984; JANIEC, MICHALCZYK, 1986; 1988; 1991; MICHALCZYK, REDEROWA, 1992; MICHALCZYK, TURCZYŃSKI, 1999). At the time of hydrographical mapping done in the Department of Hydrography, UMCS, information on the existence and yield of the springs was collected since 1953 (WILGAT, 1968; REDEROWA, 1971; MICHALCZYK, 1986; MICHALCZYK, WILGAT, 1998).

Within the next stage of spring studies of Lublin Region, the yield and quality measurements of 61 springs were conducted since 1998. Springs chosen for monitoring are typical for particular physiographic regions (Fig. 1, Tab. 1). These studies were performed in 1999-2000 within the State Committee for Scientific Research grant "Occurrence and yield of springs in Lublin Upland and Roztocze Region". These measurements were continued in 2004-2008 within the ordered grant "Extreme meteorological and hydrological events in Poland" with the aim of documenting the variability of groundwater resources in Lublin Region. Collected

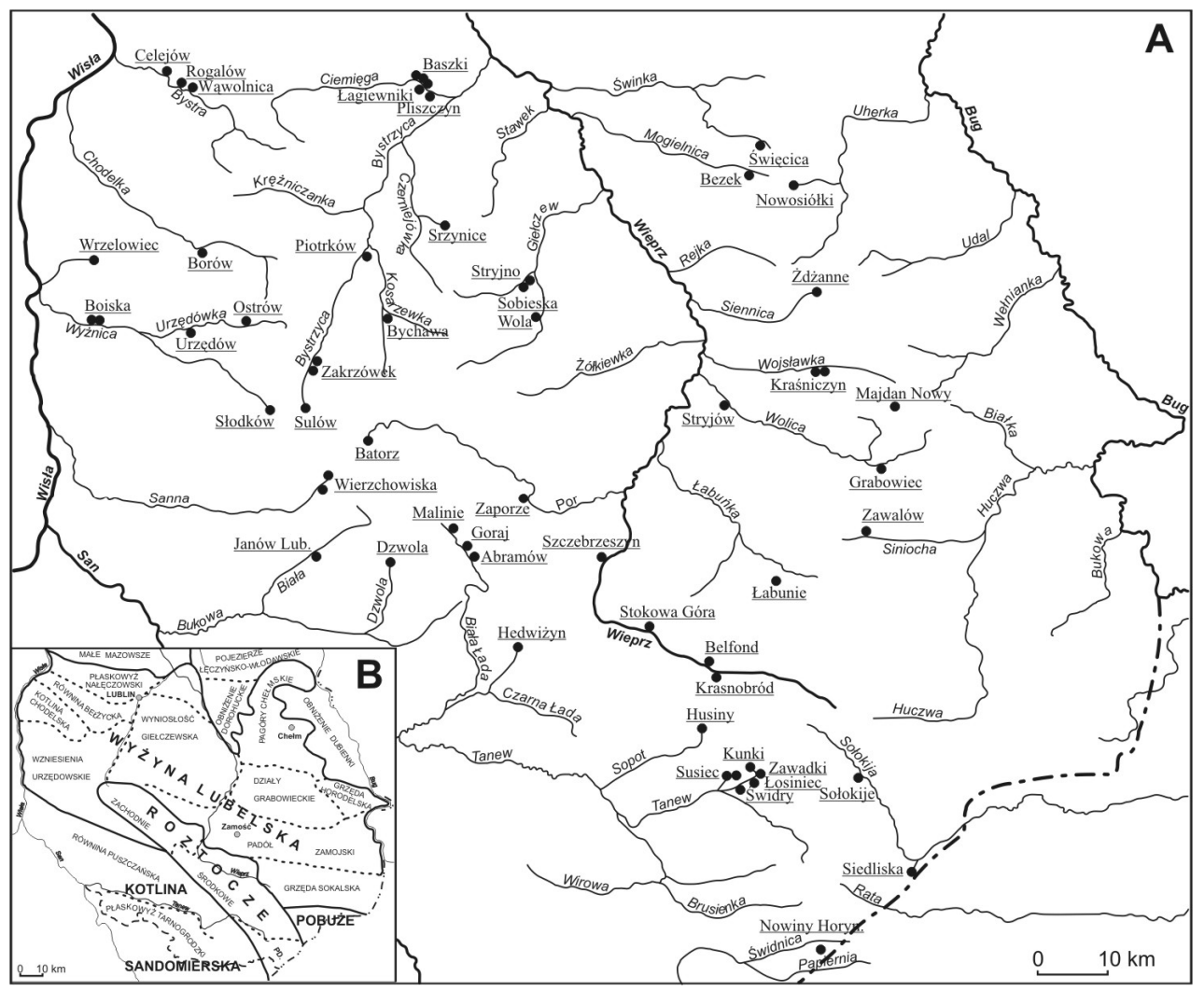

Fig. 1. Location of examined springs (A) on the background of physiographic division (B) of Lublin Region (CHAŁUBIŃSKA, WILGAT, 1954) 
Table 1. Average and extreme springs' yield in 1998-2008

\begin{tabular}{|c|c|c|c|c|}
\hline \multirow{2}{*}{ Spring - river } & \multicolumn{3}{|c|}{ Yield, $\mathrm{dm}^{3} \cdot \mathrm{s}^{-1}$} & \multirow{2}{*}{$\operatorname{Max} / \min$} \\
\hline & average & maximal & minimal & \\
\hline 1 & 2 & 3 & 4 & 5 \\
\hline \multicolumn{5}{|c|}{ Płaskowyż Nałęczowski } \\
\hline Wąwolnica - Bystra & 88.2 & 144.8 & 61.7 & 2.3 \\
\hline Rogalów - Bystra & 59.5 & 89.7 & 43.6 & 2.1 \\
\hline Celejów - Bystra & 51.5 & 64.5 & 39.2 & 1.6 \\
\hline Baszki I - Ciemięga & 40.8 & 60.6 & 25.7 & 2.4 \\
\hline Baszki II - Ciemięga & 17.5 & 26.1 & 14.2 & 1.8 \\
\hline Baszki III - Ciemięga & 18.3 & 23.0 & 12.8 & 1.8 \\
\hline Łagiewniki - Ciemięga & 6.5 & 9.0 & 5.04 & 1.8 \\
\hline Pliszczyn - Ciemięga & 44.8 & 58.6 & 31.5 & 1.9 \\
\hline \multicolumn{5}{|c|}{ Kotlina Chodelska } \\
\hline Borów - Chodelka & 33.2 & 46.2 & 24.1 & 1.9 \\
\hline Wrzelowiec - P. Wrzelow. & 36.5 & 59.4 & 20.4 & 2.9 \\
\hline \multicolumn{5}{|c|}{ Wzniesienia Urzędowskie } \\
\hline Słodków - Wyżnica & 56.9 & 109.2 & 29.3 & 3.7 \\
\hline Boiska I - Wyżnica & 22.9 & 34.6 & 17.2 & 2.0 \\
\hline Boiska II - Wyżnica & 16.8 & 27.5 & 10.8 & 2.5 \\
\hline Ostrów - Urzędówka & 30.4 & 47.9 & 19.5 & 2.5 \\
\hline Urzędów - Urzędówka & 29.0 & 48.4 & 12.2 & 4.0 \\
\hline \multicolumn{5}{|c|}{ Wyniosłość Giełczewska } \\
\hline Sulów & 52.0 & 75.4 & 28.8 & 2.6 \\
\hline Zakrzówek I - Bystrzyca & 91.2 & 222.6 & 16.3 & 13.7 \\
\hline Zakrzówek II - Bystrzyca & 118.4 & 258.5 & 71.1 & 3.6 \\
\hline Zakrzowek O - Bystrzyca & 130.6 & 182.3 & 78.1 & 2.3 \\
\hline Piotrowice - Bystrzyca & 127.6 & 183.7 & 83.0 & 2.2 \\
\hline Bychawa - Gałęzówka & 63.8 & 115.6 & 37.9 & 3.1 \\
\hline Skrzynice - Czerniejówka & 43.3 & 74.8 & 24.2 & 3.1 \\
\hline Sobieska W. - Giełczew & 91.6 & 231.1 & 37.3 & 6.2 \\
\hline Stryjno M. - Giełczew & 73.5 & 118.0 & 48.0 & 2.5 \\
\hline Stryjno D. - Giełczew & 163.4 & 356.2 & 87.4 & 4.1 \\
\hline \multicolumn{5}{|c|}{ Padół Zamojski } \\
\hline Łabunie - Łabuńka & 54.7 & 76.3 & 44.1 & 1.7 \\
\hline Zawalów - Siniocha & 19.3 & 28.4 & 13.0 & 2.2 \\
\hline \multicolumn{5}{|c|}{ Roztocze Południowe } \\
\hline Siedliska - Sołokija & 55.7 & 100.1 & 25.8 & 3.9 \\
\hline Nowiny Hor. - Papiernia & 22.9 & 30.0 & 13.5 & 2.2 \\
\hline \multicolumn{5}{|c|}{ Pagóry Chełmskie } \\
\hline Święcica - Świnka & 12.1 & 30.0 & 5.6 & 5.4 \\
\hline Bezek - Mogielnica & 12.3 & 33.3 & 7.0 & 4.8 \\
\hline
\end{tabular}


contin. tab. 1

\begin{tabular}{|c|c|c|c|c|}
\hline 1 & 2 & 3 & 4 & 5 \\
\hline Nowosiółki - Uherka & 18.3 & 49.4 & 5.6 & 8.8 \\
\hline Żdżanne - Siennica & 16.0 & 32.0 & 9.7 & 3.3 \\
\hline \multicolumn{5}{|c|}{ Działy Grabowieckie } \\
\hline Majdan N.- Wojsławka & 6.6 & 11.6 & 3.4 & 3.4 \\
\hline Kraśniczyn G.- Wojsławka & 49.1 & 97.6 & 21.6 & 4.5 \\
\hline Kraśniczyn D.- Wojsławka & 25.6 & 40.4 & 17.6 & 2.3 \\
\hline Grabowiec - Wolica & 23.1 & 29.3 & 15.2 & 1.9 \\
\hline Stryjów - Wolica & 17.3 & 20.7 & 12.6 & 1.6 \\
\hline \multicolumn{5}{|c|}{ Roztocze Zachodnie } \\
\hline Wierzchowiska Szk.-Sanna & 50.5 & 129.3 & 9.4 & 13.8 \\
\hline Wierzchowiska Stok-Sanna & 121.6 & 185.4 & 68.3 & 2.7 \\
\hline Janów - Biała & 107.3 & 130.0 & 77.2 & 1.7 \\
\hline Dzwola - Dzwola & 75.2 & 138.6 & 32.2 & 4.3 \\
\hline Malinie - Biała Łada & 181.2 & 224.0 & 147.0 & 1.5 \\
\hline Goraj - Biała Łada & 110.8 & 150.0 & 70.8 & 2.1 \\
\hline Abramów - Biała Łada & 187.2 & 251.3 & 153,0 & 1.6 \\
\hline Batorz - Por & 97.8 & 153.0 & 60.7 & 2.5 \\
\hline Zaporze - Por & 293.7 & 353.7 & 209.0 & 1.7 \\
\hline Szczebrzeszyn - Wieprz & 38.3 & 67.2 & 19.5 & 3.4 \\
\hline \multicolumn{5}{|c|}{ Roztocze Środkowe } \\
\hline Hedwiżyn - Czarna Łada & 90.9 & 117.0 & 79.4 & 1.5 \\
\hline Krasnobród - Wieprz & 152.6 & 417.2 & 20.7 & 20.2 \\
\hline Belfond - Wieprz & 75.7 & 120.5 & 46.8 & 2.6 \\
\hline Hutki - Wieprz & 239.5 & 478.9 & 107.4 & 4.5 \\
\hline Stokowa Góra - Wieprz & 167.1 & 358.3 & 98.0 & 3.7 \\
\hline Husiny - Sopot & 96.0 & 232.2 & 39.0 & 6.0 \\
\hline Zawadki - P. Łosiniecki & 62.0 & 124.6 & 35.5 & 3.5 \\
\hline Łosiniec - P. Łosiniecki & 100.6 & 176.7 & 56.4 & 3.1 \\
\hline Świdry - P. Łosiniecki & 180.3 & 339.0 & 113.3 & 3.0 \\
\hline Susiec - Jeleń & 59.1 & 80.4 & 39.3 & 2.0 \\
\hline Susiec Skwarki - Jeleń & 84.9 & 174.3 & 42.4 & 4.1 \\
\hline Sołokije - Sołokija & 204.6 & 409.2 & 121,0 & 3.4 \\
\hline
\end{tabular}

$\mathrm{Max} / \mathrm{min}$ - coefficient of irregularity of spring yield.

set of annual data from the last 11 years has monitoring character which documents changes in spring's yield together with determining the size of groundwater resources. The aim of this study is to present changes of spring yield of the upland area of Lublin Region based on homogenous data (annual measurements in spring time) as the indicator of underground resources of Cretaceous or Tertiary multiaquifer formation. 
Yield of springs determines river water resources, which are fed exclusively by groundwaters in dry periods. The share of underground feeding in the river outflow is $74 \%$, and spring feeding reaches $24 \%$ (Źródła..., 2001). Minimal specific runoffs from the catchments of the upland area do not drop below $1 \mathrm{dm}^{3} \cdot \mathrm{s}^{-1} \cdot \mathrm{km}^{-2}$, which indicates abundant water resources.

\section{HYDROGEOLOGICAL CONDITIONS OF SPRINGS EXISTENCE}

Study area is located within the hydrogeological region of Lublin Cretaceous Formation. Water circulation in the active zone of turnover takes place in carbonate rocks of Upper Cretaceous formed as opokas, gaizes, marls and chalk (WYRWICKA, 1977). In north-western part the water bearing horizon occurred also in Palaeocene gaizes and marl limestones, and in the southern one - in Neogene limestones and sandstones (Budowa..., 1991). In both vertical profile and regional scale the occurrence of particular types of rocks distinctly varies and the existing rock layers slow down the seepage and formation of upper levels (WILGAT, 1970; MiCHALCZYK, WILGAT, 1998). In the areas between river valleys firm carbonate rocks are covered with thin layer of sand-dusty formations, loesses and clays. Erosive dissections and river valleys are filled with Pleistocene and Holocene sandy formations, alluvia and organic sediments.

Tectonically, upland area was formed during Young Alpine uplift movements which took place in Lower Baden and Sarmatia and the Quaternary (POŻARYSKI, 1974). Systems of fissures cut firm carbonate rocks and open fissures create good conditions for groundwater flow. According to geomorphological studies, lines of the main tectonic zones are reflected in valleys structure and in morphological escarpment system (JAHN, 1956; MARUSZCZAK, 1972).

Useful groundwater aquifer was created in pored and fissured Cretaceous rocks and locally in Tertiary and Quaternary sediments. These rocks most often form one series of aquifers with water table corresponding to surface relief, only locally perched waters are found. The highest level of groundwater can be found in Roztocze Środkowe (280-300 m a.s.1.), and the lowest one - in the Vistula River valley near Puławy (115 m a.s.l.). In valleys the groundwater table occurs very shallowly - below $2 \mathrm{~m}$. In the valley's edges the thickness of unsaturated zone increases to several metres and in the hilltop it reaches even $60-80 \mathrm{~m}$. Conditions for feeding groundwater resources by precipitation seepage are considered good because of good or medium permeability of the surface rocks. It determines large water resources and balanced inflow into rivers, also through springs. Water resources and good conditions of fissure flow provide stability in springs' feeding. Spring waters are characterized by natural chemical composition, high water quality and slight effect of human impact (MICHALCZYK et al., 2004). 


\section{AVERAGE AND EXTREME SPRING YIELD}

Springs with quite high yield are typical for Lublin and Roztocze Regions (JANIEC, MiCHALCZYK, 1986; 1988; 1991; Źródła..., 2001; MiCHALCZYK et al., 2004). Spring studies described in cited papers are based on different length of measurement series of springs yield collected in 1949-2004. In some outflows, daily water levels were registered (Wąwolnica, Goraj, Wierzchowiska, Krasnobród, Szczebrzeszyn, Janów), and in the others discharge measurements were made irregularly. Published materials based on these irregular measurements document slight variability of the biggest outflows' yield in Lublin Region because the variability of almost $70 \%$ of springs did not exceed 5 and usually were within the range 1.6-3.8. In quite stable yield rhythm, seasonal fluctuations impose on annual yield changes. Very high springs' yield values were observed in 1967-1968, 1971-1972, 1975-1976, 1980-1982 and 1999-2002, very low yields - in 1964-1965, 1973-1974, 1984-1985 and 1991-1993 (MICHALCZYK et al., 2004).

Spring yield depends on climate and local factors, and among them permeability of the surface grounds, lithology and rock fissure, land use and surface relief are the most important. These conditions determine the quantity and regime of outflowing water which can be seen in registered springs (Tab. 1), grouped in physiographic regions presented by CHAŁUBIŃSKA and WILGAT (1954). A characteristic of yield was prepared in the hydrological aspect, with the attempt to search for regional changes in the area of carbonate rocks occurrence. In the paper the average yield for 11 measurements and extreme values were presented. In order to examine regional changes of springs' yield in Lublin Upland and Roztocze Region, in spring periods of 1998-2008 every-year measurements of the most efficient springs were made. Despite vast study area the measurements were conducted during one month to ensure comparability of results.

In the areas of shallow occurrence of fissured Cretaceous rocks fast reaction to precipitation was observed, for example in springs of the eastern part of Lublin Upland and Roztocze Tomaszowskie region (Nowosiółki, Sołokije, Husiny, Łosiniec). However, in the areas of loesses occurrence, slow and rather long-term changes of springs' yield were observed, for example in springs of Płaskowyż Nałęczowski, Roztocze Zachodnie, and Działy Grabowieckie. Coefficients of yield variability calculated for the period 1998-2008 had values in the range 1.5-6.0 (and 70\% of them within even narrower range between 1.5 and 3.5 - Table 1), which confirms high regularity of outflow from the biggest springs in Lublin Upland and Roztocze Region (Żródła..., 2001). Only several outflows were characterised by the variability exceeding 10. The springs Zakrzówek I, Wierzchowiska (spring near the school), Krasnobród during very dry periods of the second half of the 20th century periodically disappeared.

Annually the analysed springs together delivered $4600 \mathrm{dm}^{3} \cdot \mathrm{s}^{-1}$ of water, which corresponds to the mean outflow of $76.1 \mathrm{dm}^{3} \cdot \mathrm{s}^{-1}$. In 2000, when the level of 
groundwater was very high, spring efficiency amounted $7400 \mathrm{dm}^{3} \cdot \mathrm{s}^{-1}$, but in 2004 it decreased to $3500 \mathrm{dm}^{3} \cdot \mathrm{s}^{-1}$. Average value of maximum outflow was 132.7 $\mathrm{dm}^{3} \cdot \mathrm{s}^{-1}$, while that of the minimum $-44.7 \mathrm{dm}^{3} \cdot \mathrm{s}^{-1}$. Therefore, mean coefficient of the yield variability of the springs equalled 3.0.

\section{VARIABILITY OF SPRINGS' YIELD}

Former studies (MICHALCZYK, 1982; 1986; Źródła..., 1993; Źródła..., 1996; Źródła..., 2001) on springs' yield in Lublin Upland and Roztocze Region showed long-term and seasonal cycle of its changes which was related to the conditions of circulation and the quantity of groundwater feeding. During the study period total amount of water outflowing from the springs in the first years increased from 4740 $\mathrm{dm}^{3} \cdot \mathrm{s}^{-1}$ to the maximum yield of $7400 \mathrm{dm}^{3} \cdot \mathrm{s}^{-1}$ registered in 2000. Springs' yield in 2000 was even a little higher than in previous wet years. In the following years it ranged between 3500 and $4900 \mathrm{dm}^{3} \cdot \mathrm{s}^{-1}$, while recently it has dropped too much lower level, generally below the long-term average. Changes of yield converted to average outflow varied from 56.6 to $120.8 \mathrm{dm}^{3} \cdot \mathrm{s}^{-1}$ (Fig. 2).

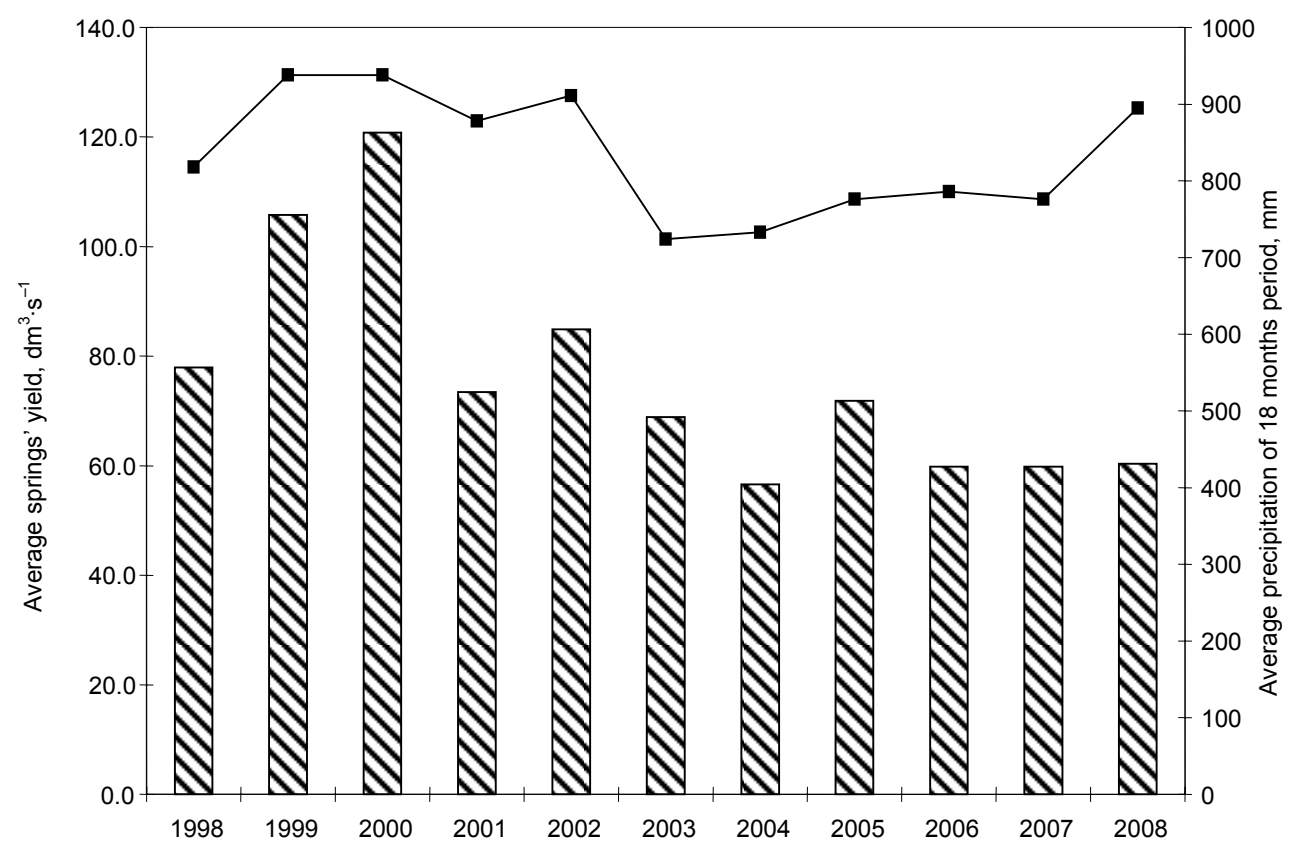

Fig. 2. Average yield of measured springs and sum of precipitation for 18 months (former year + winter half-year) 
Springs' yield depends mainly on precipitation. However, various times of springs' reaction to feeding and changes in the outflow were observed. It results from lithology of the surface rocks, from lithologic variability and fissures in the aquifer rocks. Comparison of the monthly sums of precipitation and springs' yield does not show correlation between feeding and runoff. Observations and analyses showed that restocking of underground resources took place in the cold half-year, and that there was a shift between high feeding and increasing of the spring yield. Significant relations were observed, as in the former papers (MICHALCZYK, 1982; 1983; 1988; MICHALCZYK, REDEROWA, 1992), between shifted and elongated feeding period and springs' yield. It points out to the longer time of reaction of springs to feeding and to a high retention capacity of the ground.

Searching for relations between precipitation and spring's yield was continued by extending the precipitation period preceding measurements of outflowing water quantity. Figure 2 shows sum of precipitation from the former year and winter halfyear and springs' yield measured every time in May to June. Because of the lack of precipitation data for particular physiographic regions, presented data originate from one station - Lublin Radawiec, the only one for which such data for spring study period were available. Despite generalization of total precipitation in the regional scale, considerable relationships between shifted feeding and springs' yield were observed. Similar relationships were obtained when the feeding period was extended to 2.5 years - two former years and winter half-year (Fig. 3), in rela-

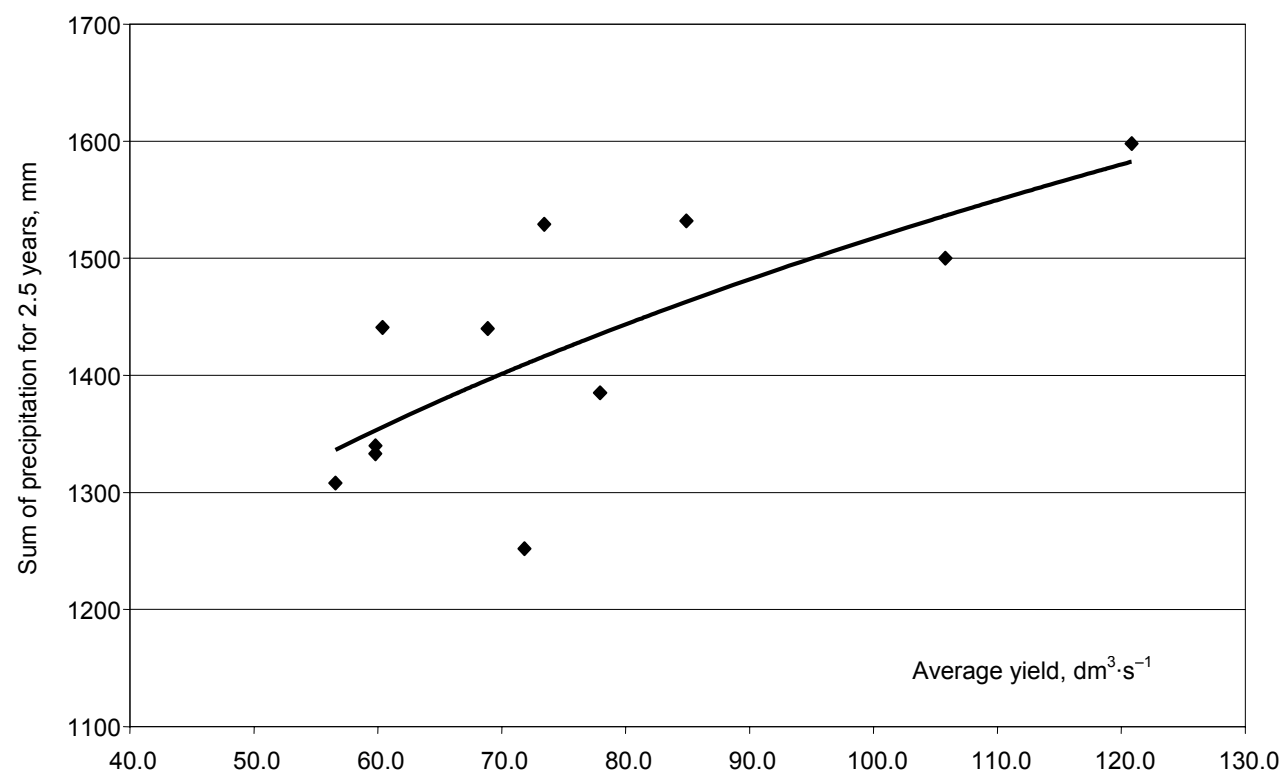

Fig. 3. Relationship between springs' yield and feeding in 2.5 years period (two former years and winter half-year) 
tion to averaged spring yield measured in that year. It should be mentioned that the winter half-year when precipitation was usually larger than evaporation, had larger impact on improving precipitation - spring's yield relationships. Longer time of springs' reaction to feeding is influenced by the conditions of retention and water flow in pore-fissured water-bearing bed covered with dust-sandy sediments in unsaturated zone.

Feeding and hydrogeological conditions are clearly visible in the regional variability of yield and regime of outflowing water. Analysis of changes of yield was conducted with reference to physiographic division made by CHAŁUBIŃSKA and WILGAT (1954). Typical yields of monitored springs are compared in Table 1, while Figure 4 shows results of measurements for selected springs typical for particular regions. Constant vertical and horizontal scale was applicable on the chart, so it enables to compare springs' yield and its changes in particular parts of the examined area. Simultaneously, those charts document yearly changes of the yield. The most efficient springs, with seasonal mean over $400 \mathrm{dm}^{3} \cdot \mathrm{s}^{-1}$, exist in the Roztocze Środkowe in the area built of gaizes and opokas. The lowest yield with low variability was observed in the eastern part of Lublin Upland, in the area built of soft marls and chalk. In the zones of shallow occurrence of fissured opokas, gaizes and hard marls covered by thin sand layer many springs can be found of distinct annual variability of the yield (Fig. 4). In the areas covered with loess the spring yield is regular.

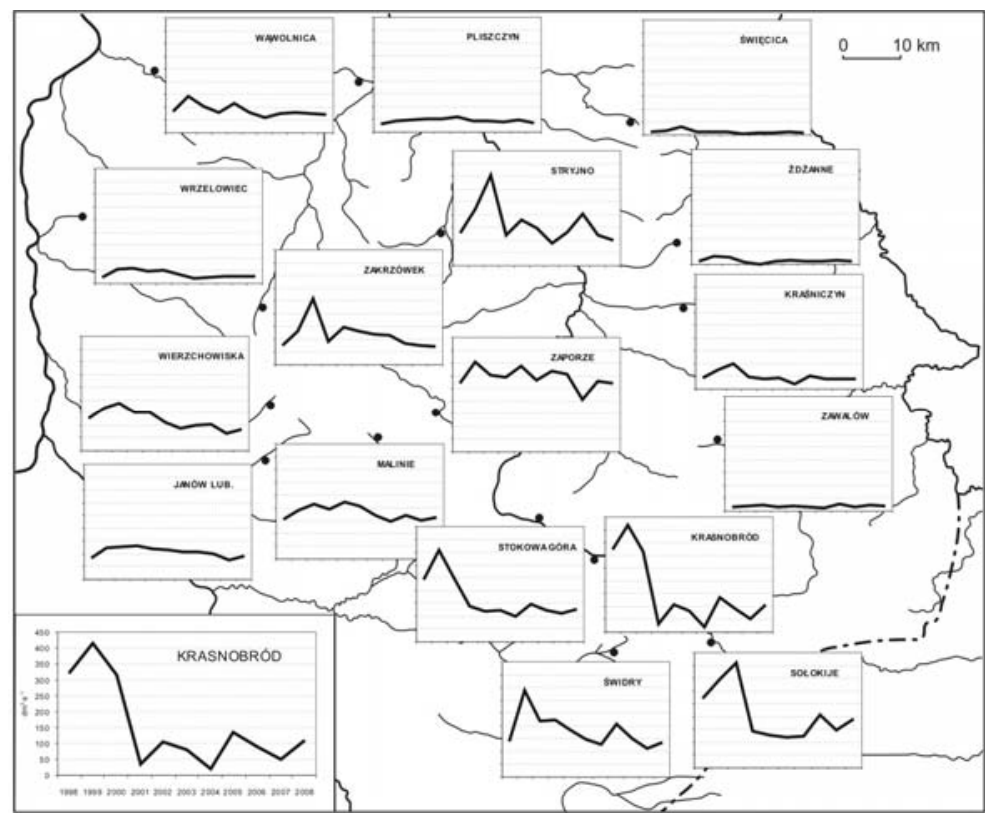

Fig. 4. Yield variability in selected springs of Lublin Upland and Roztocze Region in the years 1998-2008 
In order to show regional character of yield changes, average springs' yields in particular regions were compared and presented in Figure 5. The vertical axis of all charts shows yield from 0 to $220 \mathrm{dm}^{3} \cdot \mathrm{s}^{-1}$, the horizontal one - annual yield in years the 1998-2008. Springs in particular regions are not equally represented in displayed data because their number varies from 2 to 13 . In each year average values were calculated from the same amount of springs on the basis of measurements performed in late spring season. Therefore, obtained values do not represent an average year although they are probably very similar to them. Highest average yield was found in the Roztocze Srodkowe in 1999 and in other regions in 2000 (Fig. 5). Lowest values were noted in 2004 and in 2008. In the years 1998-2008 the highest variability of yield was noticed in Środkowe and Zachodnie Roztocze as well as in Wyniosłość Giełczewska. Springs’ yield in other regions was more stable.

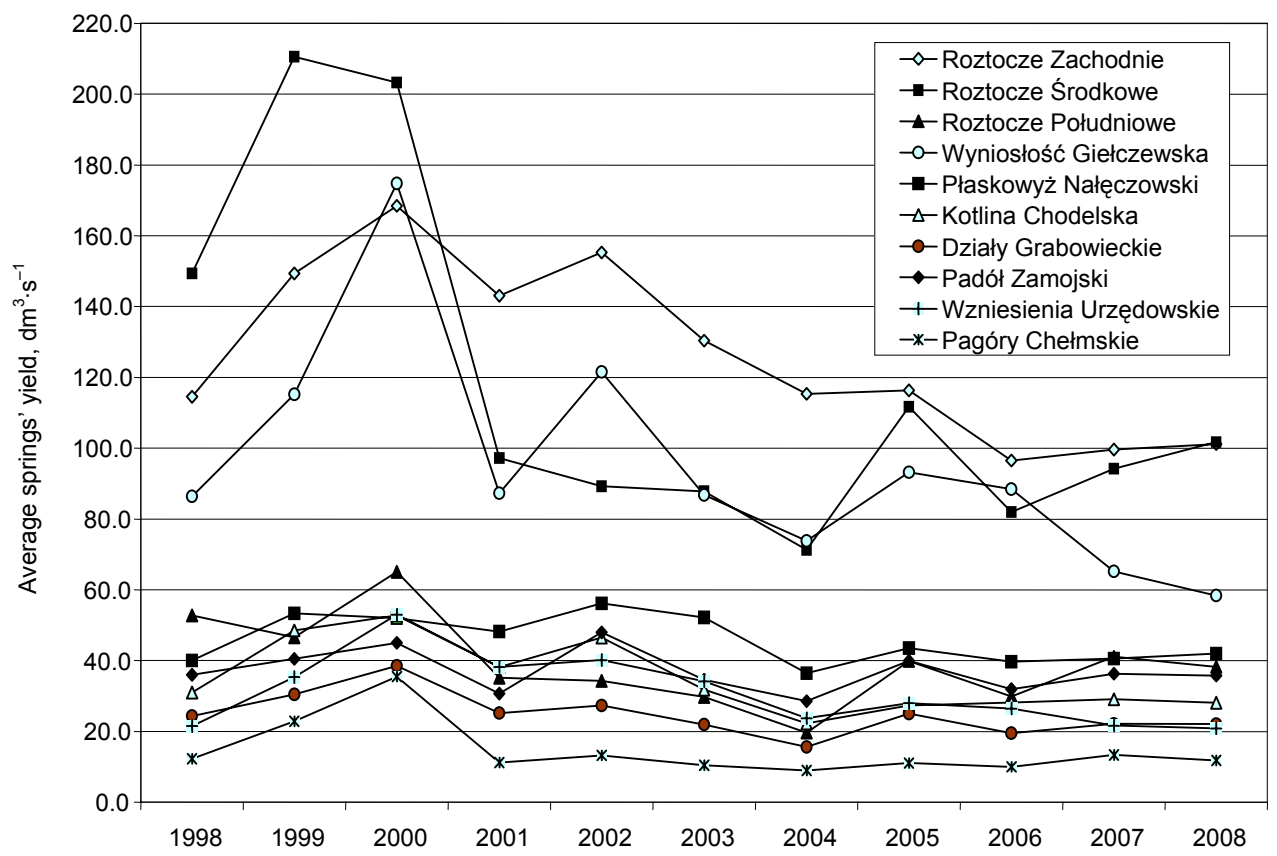

Fig. 5. Average springs' yield in physiographic regions

\section{SUMMARY}

In the spring time of 1998-2008 measurements of 61 most typical springs of Lublin Upland and Roztocze Region were made. Apart from the Tatra Mountains this is the area of most abundant occurrence of springs in Poland. Collected hydrometric data showed regional variability of feeding conditions of rivers by 
groundwaters. Only indirectly they indicate variability of hydrogeological conditions of the region, which is characterized by abundant springs of the yield reaching $400 \mathrm{dm}^{3} \cdot \mathrm{s}^{-1}$. The same sampling period and terms of measurements enabled to compare average and extreme yield values in the period of 11 years. Average springs' yield amounted $76.1 \mathrm{dm}^{3} \cdot \mathrm{s}^{-1}$, while mean minimum efficiency was 44.7 $\mathrm{dm}^{3} \cdot \mathrm{s}^{-1}$ and mean maximum $-132.7 \mathrm{dm}^{3} \cdot \mathrm{s}^{-1}$. Therefore, average irregularity coefficient equalled only 3.0. Slight variability of spring yield was reflected in regular river feeding by groundwater resources. Annually measured springs delivered in total $4600 \mathrm{dm}^{3} \cdot \mathrm{s}^{-1}$ of high quality water. In 2000 , at the time of high level of underground water, the total efficiency was $7400 \mathrm{dm}^{3} \cdot \mathrm{s}^{-1}$, but in 2004 it was only 3500 $\mathrm{dm}^{3} \cdot \mathrm{s}^{-1}$. In the first years of studies - till 2000 - springs' yield was increasing. In the following years it was stable and remained at a level of long-term average values. Irregularity coefficient of springs changed in most cases in the range 1.5-5.0. These values allow for describing springs as outflows of stable and slightly variable yield. In several cases irregularity of yield was higher because of hydrological and meteorological conditions or local factors, associated with economic use of spring waters.

The study was performed within the State Committee for Scientific Research grant: PBZKBN-086/PO4/2003.

\section{REFERENCES}

1. Budowa geologiczna Polski. T. 7. Hydrogeologia, (Geologic structure of Poland. Vol. 7. Hydrogeology), 1991. Ed. J. Malinowski. Warszawa, Wydaw. Geol.: 275.

2. Chalubińska A., Wilgat T., 1954. Podział fizjograficzny województwa lubelskiego. (Physiographic division of the Lublin voivodship). Przew. V Ogólnop. Zjazdu PTG. Lublin: 3-44.

3. CZARNECKA H., 1965: Obserwacje i pomiary źródeł. (Observations and measurements of springs). Prace i Studia Kom. Inż. i Gosp. Wodnej, 7: 215-221.

4. DOBORZYŃSKI S., 1896. Przyczynek do wyjaśnienia sposobu powstania źródeł żelazistych w okolicach Lublina. (Contribution to the explanation of the origin of ferrous springs near Lublin). Pamiętnik Fizjograf. 14, 2: 13-15.

5. JAHN A., 1956. Wyżyna Lubelska. Rzeźba i czwartorzęd. (Lublin Upland. Relief and the Quaternary). Prace Geogr. IG PAN, 7: 453.

6. JANIEC B., 1984. Wody podziemne w strefie południowo-zachodniej krawędzi Wyżyny Lubelskiej. (Ground waters at the south-western edge of Lublin Upland). Warszawa, Wydaw. Geol.: 137.

7. JANIEC B., MiCHALCZYK Z., 1986. Charakterystyka wybranych źródeł Roztocza Zachodniego i południowo-zachodniej krawędzi Wyżyny Lubelskiej. W: Rozwój regionalnych badań hydrogeologicznych w Polsce. (Characteristics of selected springs of Roztocze Zachodnie and south-western edge of Lublin Upland. In: Development of regional hydrogeological studies in Poland). Kraków, Wydaw. AGH: 209-217.

8. JANIEC B., MichalCZYK Z., 1988. Wybrane problemy krenologiczne Roztocza Zachodniego. W: Badania hydrograficzne w poznawaniu środowiska. (Selected problems of krenology in Zachodnie 
Roztocze. In: Hydrographic studies in environmental recognition). Lublin, Wydaw. UMCS: 173$-206$.

9. JANIEC B., MiCHALCZYK Z., 1991. Wydajność i skład chemiczny wód największych źródeł Roztocza i Wyżyny Lubelskiej. W: Współczesne problemy hydrogeologii. (The efficiency and chemical composition of waters from the largest springs of Roztocze and Lublin Upland. In: Current problems of hydrogeology). Warszawa, Wydaw. SGGW-AR: 134-139.

10. KRISZTAFOWICZ N.I., 1902. Gidro-geologičeskoe opisane teritorii goroda Ljublina i jego okresnostej. (Hydrogeologic description of Lublin and its surroundings). Warszawa: 293.

11. MALINOWSKI J., 1974. Hydrogeologia Roztocza Zachodniego. (Hydrogeology of Zachodnie Roztocze). Prace Hydrogeol., spec., 6.

12. MaruszczaK H., 1972. Wyżyny Lubelsko-Wołyńskie. W: Geomorfologia Polski. T. 1. (LublinWołyń Uplands. In: Geomorphology of Poland. Vol. 1). Warszawa: 340-384.

13. MiCHALCZYK Z., 1982. Charakterystyka hydrogeologiczna dorzecza Łady. Z badań hydrogeologicznych w Polsce. T. 6. (Hydrogeologic characteristics of the Łada catchment basin. From hydrogeological studies in Poland. Vol. 6). Biuletyn IG 339: 109-161.

14. MichalczYK Z., 1983a. Źródła Sanny w Wierzchowiskach. (Springs of the Sanna in Wierzchowiska). Ann. UMCS, B, 35/36: 175-192.

15. MichalCZYK Z., 1983b. Charakterystyka hydrologiczna źródła w Szczebrzeszynie. (Hydrologic characteristics of a spring in Szczebrzeszyn). Ann. UMCS, B, 35/36, 1: 93-207.

16. MiCHALCZYK Z., 1986. Warunki występowania i krążenia wód na obszarze Wyżyny Lubelskiej i Roztocza. (The occurrence and cycling of waters on Lublin Upland and Roztocze). Lublin, Wydaw. UMCS: 195.

17. MiCHALCZYK Z., 1988. Źródła Białej Łady w okolicy Goraja. (Springs of the Biała Łada near Goraj). Ann. UMCS, B, 36/36: 267-287.

18. MichalCZYK Z., CHMiel S., GŁOWACKi S., ZielińSKA B., 2004. Zmiany wydajności i chemizmu wód źródeł Wyżyny Lubelskiej i Roztocza. (Changes in the efficiency and chemical composition of spring waters on Lublin Upland and Roztocze). Ann. UMCS, B, 59: 107-122.

19. MichalczyK Z., Rederowa E., 1992. Charakterystyka hydrologiczna źródeł okolic Zakrzówka. (Hydrologic characteristics of springs near Zakrzówek). Ann. UMCS, B, 44/45: 169-186.

20. MichalCZYK Z., TURCZYŃSKI M., 1999. Charakterystyka hydrologiczna źródeł w Wąwolnicy na Wyżynie Lubelskiej. (Hydrologic characteristics of springs in Wąwolnica on Lublin Upland). Ann. UMCS, B, 54: 217-234.

21. MichalczyK Z., Wilgat T., 1998. Stosunki wodne Lubelszczyzny. (Water relations in the Lublin region). Lublin, Wydaw. UMCS.

22. POŻARYSKI W., 1974. Obszar świętokrzysko-lubelski. W: Budowa geologiczna Polski. T. 4. Tektonika. (Świętokrzysko-lubelski region. In: Geologic structure of Poland Vol. 4. Tectonics). Cz. 1: 314

-362 .

23. Rederowa E., 1965. Źródła Bystrzycy Lubelskiej. (Springs of the Bystrzyca Lubelska). Ann. UMCS, B, 18: 229-244.

24. REDEROWA E., 1971. Występowanie źródeł na Wyżynie Lubelskiej i w obszarach przyległych. (The occurrence of springs on Lublin Upland and in nearby areas). Prz. Geogr., 43, 3: 355-360.

25. Strategia wykorzystania i ochrony wód w dorzeczu Bystrzycy, (The strategy of water protection and utilisation in the Bystrzyca catchment basin), 1997. Ed. Z. Michalczyk. Lublin, Wydaw. UMCS: 192.

26. Wilgat T., 1968. Przeglądowa mapa hydrogeograficzna województwa lubelskiego. (Survey hydrogeographic map of the Lublin voivodship). Ann. UMCS, B, 20: 223-242.

27. WiLGAT T., 1970. Kontrowersja na temat sposobu występowania wód w kredzie lubelskiej. (Controversy on the way of occurrence of waters in the Lublin Cretaceous deposits). Prz. Geogr., 42, 1: 57$-68$. 
28. WYRWICKA K., 1977. Wykształcenie litologiczne i węglanowe surowce skalne mastrychtu lubelskiego. Z badań złóż surowców skalnych w Polsce. T. 9. (Lithologic formation and carbonate rocks of the Lublin Mastricht. From studies of rock deposits in Poland. Vol. 9). Biul. IG, 299: 5-98.

29. Źródła zachodniej części Wyżyny Lubelskiej, (Springs of the western part of Lublin Upland), 1993. Ed. Z. Michalczyk. Lublin, Wydaw. UMCS: 199.

30. Źródła Roztocza. Monografia hydrograficzna, (Springs of Roztocze. Hydrographic monograph), 1996. Ed. Z. Michalczyk. Lublin, Wydaw. UMCS: 200.

31. Źródła Wyżyny Lubelskiej i Roztocza, (Springs of Lublin Upland and Roztocze), 2001. Ed. Z. Michalczyk. Lublin, Wydaw. UMCS: 298.

\section{STRESZCZENIE}

\section{Zmiany wydajności źródel Wyżyny Lubelskiej i Roztocza w latach 1998-2008}

Słowa kluczowe: nieregularność wydajności, wydajność, Wyżyna Lubelska i Roztocze, źródta

W latach 1998-2008 wykonywano w okresach wiosennych pomiary wydajności 61 charakterystycznych źródeł Wyżyny Lubelskiej i Roztocza. Jest to obszar występowania najwydajniejszych, poza regionem tatrzańskim, źródeł w Polsce. Zebrane materiały hydrometryczne świadczą o istotnym regionalnym zróżnicowaniu warunków zasilania rzek wodami podziemnymi. Tylko pośrednio wskazują na zmienność warunków hydrogeologicznych regionu, którego cechą jest występowanie wydajnych źródeł o wydajności dochodzącej nawet do $400 \mathrm{dm}^{3} \cdot \mathrm{s}^{-1}$. Wydajność źródeł w znacznym stopniu decyduje o zasobności w wodę rzek, które w okresie bezopadowym są zasilane wyłącznie z zasobów podziemnych. Minimalne odpływy jednostkowe ze zlewni rzek wyżynnych praktycznie nie zmniejszają się poniżej $1 \mathrm{dm}^{3} \cdot \mathrm{s}^{-1} \cdot \mathrm{km}^{-2}$, co wskazuje na znaczne zasoby wód podziemnych.

Zebrane jednorodne materiały hydrometryczne umożliwiają porównanie wydajności średnich i skrajnych w okresie 11 lat na zróżnicowanym fizjograficznie obszarze Wyżyny Lubelskiej i Roztocza. Średnia wydajność 61 mierzonych źródeł wynosiła $76,1 \mathrm{dm}^{3} \cdot \mathrm{s}^{-1}$, natomiast średnia $\mathrm{z}$ minimalnych wydatków zmniejszyła się do $44,7 \mathrm{dm}^{3} \cdot \mathrm{s}^{-1}$, a $\mathrm{z}$ maksymalnych zwiększyła do $132,7 \mathrm{dm}^{3} \cdot \mathrm{s}^{-1}$. Zatem średni współczynnik nieregularności wydatku mierzonych źródeł wynosi tylko 3,0. Corocznie mierzone źródła dostarczały łącznie $4600 \mathrm{dm}^{3} \cdot \mathrm{s}^{-1}$ wody. W $2000 \mathrm{r}$., gdy stany wody podziemnej były wysokie, łączna wydajność osiagnęła $7400 \mathrm{dm}^{3} \cdot \mathrm{s}^{-1}$, a w $2004 \mathrm{r}$. obniżyła się do $3500 \mathrm{dm}^{3} \cdot \mathrm{s}^{-1}$. W pierwszych latach pomiarów - do 2000 r. - wydajność źródeł się zwiększała. W następnych latach utrzymywała się ona na poziomie wartości średnich $\mathrm{z}$ wielolecia. Współczynnik nieregularności wydajności źródeł przyjmował przeważnie wartości w zakresie 1,5-5,0, w związku z czym można zaliczyć badane źródła do grupy wypływów o stałej i mało zmiennej 
wydajności. W kilku przypadkach nieregularność wydatku źródeł była większa, o czym decydowały warunki hydrogeologiczne i meteorologiczne oraz czynniki lokalne, między innymi związane z gospodarczym wykorzystaniem wody.

Received 31.10.2008

Reviewers:

Prof. Matgorzata Gutry-Korycka

Dr Krzysztof Jóźwiak

Dr Robert Żurawski 